\title{
Biallelic inactivation of the SDHC gene in renal carcinoma associated with paraganglioma syndrome type 3
}

\author{
Angelica Malinoc ${ }^{1}$, Maren Sullivan ${ }^{1}$, Thorsten Wiech', \\ Kurt Werner Schmid ${ }^{3}$, Cordula Jilg, Joern Straeter ${ }^{5}$,'Serdar Deger ${ }^{6}$, \\ Michael M Hoffmann ${ }^{7}$, Alexander Bosse ${ }^{8}$, Gerd Rasp', \\ Charis Eng ${ }^{10,11,12}$ and Hartmut P H Neumann ${ }^{1}$
}

Departments of ${ }^{1}$ Nephrology and General Medicine and ${ }^{2}$ Pathology, University Medical Center, Albert-Ludwigs-University, Freiburg, Germany

${ }^{3}$ Department of Pathology and Neuropathology, University Hospital of Essen, University of Duisburg-Essen, Essen, Germany

${ }^{4}$ Department of Urology, University Medical Center, Albert-Ludwigs-University, Freiburg, Germany

${ }^{5}$ Institute of Pathology, Esslingen, Germany

${ }^{6}$ Department of Urology, Hospital Ruit, Ostfildern, Germany

${ }^{7}$ Division of Clinical Chemistry, University Medical Center, Albert-Ludwigs-University, Freiburg, Germany

Departments of ${ }^{8}$ Pathology and ${ }^{9}$ Otolaryngology, Katharinen Hospital, Stuttgart, Germany

${ }^{10}$ Genomic Medicine Institute, ${ }^{11}$ Lerner Research Institute and ${ }^{12}$ Taussig Cancer Institute, Cleveland Clinic, Cleveland, Ohio, USA

(Correspondence should be addressed to H P H Neumann who is now at Medizinische Universitätsklinik, Abteilung Innere Medizin 4, Sektion für Präventive Medizin, Hugstetter Strße 55, D 79106 Freiburg, Germany; Email: hartmut.neumann@uniklinik-freiburg.de)

\begin{abstract}
The etiology and pathogenesis of renal cell carcinoma $(\mathrm{RCC})$ are only partially understood. Key findings in hereditary RCC, which may be site specific or a component of a syndrome, have contributed to our current understanding. Important heritable syndromes of RCC are those associated with pheochromocytoma, especially von Hippel-Lindau disease (VHL) associated with germline $V H L$ mutations, and pheochromocytoma and paraganglioma syndrome (PGL) associated with mutations in one of the four genes (SDHA-D) encoding succinate dehydrogenase. A subset of individuals with $S D H B$ and $S D H D$ germline DNA mutations and variants develop RCC. RCC has never been described as a component of $S D H C$-associated PGL3. The European-American Pheochromocytoma and Paraganglioma Registry comprises 35 registrants with germline $S D H C$ mutations. A new registrant had carotid body tumor (CBT) and his mother had CBT and bilateral RCC. Blood DNA, paragangliomas, and RCCs were analyzed for mutations and loss-of-heterozygosity ( $\mathrm{LOH}$ ) in/flanking $S D H C$ and $V H L$. The proband with unilateral $C B T$ had a germline $S D H C$ c.3G $>$ A (p.M1I) mutation. His mutation-positive mother had CBT at age 42, clear cell RCC (ccRCC) at age 68, and papillary RCC (pRCC) at age 69. Both paraganglial tumors showed somatic LOH of the SDHC locus. Both ccRCC and pRCC did not have a somatic $S D H C$ mutation but showed $\mathrm{LOH}$ for intragenic and flanking markers of the $S D H C$ locus. $\mathrm{LOH}$ was also present for the $\mathrm{VHL}$ locus. Our findings suggest that RCC is a component of PGL3. Biallelic inactivation of the $S D H C$ gene may represent a new pathway of pathogenesis of syndromic and nonsyndromic RCC, perhaps of both clear cell and papillary histologies.
\end{abstract}

Endocrine-Related Cancer (2012) 19 283-290

\section{Introduction}

Pheochromocytoma-related syndromes have contributed to our understanding of the pathogenesis of renal cell carcinomas (RCCs; Pavlovich \& Schmidt 2004, Gill et al. 2011 b). In particular, two heritable syndromes have been recognized to confer a risk of RCC. von Hippel-Lindau disease (VHL) is associated with clear cell RCC (ccRCC) in about $30 \%$ of the affected patients. The other, pheochromocytoma/paraganglioma syndrome (PGL), associated with germline succinate dehydrogenase $(S D H B)$ mutations has been particularly associated with increased risk of RCC 
(Vanharanta et al. 2004, Ricketts et al. 2008, Gill et al. 2011a,b). Renal parenchymal neoplasias are classified as RCC and benign tumors. RCCs include ccRCC, papillary RCC (pRCC), chromophobe RCC, and RCC of unclassified cell type. The most prevalent are ccRCCs occurring in about $65 \%$ of parenchymal malignancies followed by pRCCs accounting for $15 \%$ of all RCCs (Delahunt \& Eble 2004, Grignon et al. 2004, Cohen \& McGovern 2005).

The most well-described disorder comprising both ccRCC and pheochromocytoma is VHL, a relatively common autosomal dominant heritable endocrine neoplasia syndrome, caused by germline mutations in the VHL tumor suppressor gene on 3p25-p26 (Lonser et al. 2003). Renal tumors in VHL are always ccRCC and almost always associated with germline-truncating mutations in the $V H L$ gene.

Recently, heritable ccRCC associated with pheochromocytoma and paraganglioma has been described as a consequence of germline heterozygous mutations of the gene-encoding subunit B of the enzyme $S D H B$ by at least two independent groups (Vanharanta et al. 2004, Ricketts et al. 2008). Interestingly, germline variation in $S D H B / D$ has been found to account for $10 \%$ of the Cowden heritable cancer syndrome without mutations in its major susceptibility gene PTEN and that those with $S D H B / D$ variants have an increased prevalence of RCC over those with germline PTEN mutations (Ni et al. 2008, 2012).

Succinate dehydrogenase lies at the crossroads of the Krebs tricarboxylic acid cycle and the electron transport chain. SDH catalyzes succinate to fumarate, which is the substrate of fumarate hydratase $(F H)$. Germline $F H$ mutations are associated with hereditary type 2 pRCC (Tomlinson et al. 2002). Site-specific pRCC has been described as a familial disease associated with germline gain-of-function mutations of the MET proto-oncogene encoding a receptor tyrosine kinase (Schmidt et al. 2004). In contrast to $F H$-associated pRCCs, which are type 2 papillary histology, pRCCs associated with $M E T$ mutations are type 2. Chromophobe (sometimes papillary) RCC is a component of Birt-Hogg-Dube syndrome associated with mutations of the $B H D$ (FLCN) gene located on chromosome 17 (Schmidt et al. 2001, Khoo et al. 2002). Other component phenotypes of these latter patients include fibrofolliculomas, lung cysts, and pneumothorax.

As we and others have described that patients with germline mutations of the $S D H B$ gene develop RCC in the setting of hereditary pheochromocytoma/PGL as well as Cowden syndrome, we sought to address the hypothesis that germline mutations in $S D H C$ may also be associated with RCC by interrogating the population-based European-American Pheochromocytoma and Paraganglioma Registry for kidney tumors in patients and family members with germline mutations in the SDHC gene (Neumann et al. 2004, Vanharanta et al. 2004, Ni et al. 2008).

\section{Patients and methods}

\section{Patients}

As of October 1, 2011, the population-based EuropeanAmerican Pheochromocytoma and Paraganglioma Registry comprised a total of more than 2000 registrants, of which 35 had germline mutations of the SDHC gene, mainly head and neck paragangliomas. Originally, SDHC mutations were only related to head and neck PGL (Schiavi et al. 2005). When it became evident that SDHC mutation carriers might also have a risk of pheochromocytomas and paragangliomas of the abdomen and thorax (Peczkowska et al. 2008), we informed all 35 SDHC mutation-positive patients to undergo clinical screening by magnetic resonance imaging (MRI) of the thorax and abdomen. We were also cognizant to inspect other organs, such as the kidneys.

We obtained written informed consent from both the research participants, the original index registrant (proband), and his mother, in accordance with an approved protocol deriving from our institutions' Institutional Review Board for Human Research Subjects' Protection.

\section{Genetic analysis}

For purposes of mutation analysis, we obtained from both the registrants $10 \mathrm{ml}$ each EDTA-anticoagulated blood and paraffin blocks of the carotid body tumors (CBTs) from both the patients as well as paraffin blocks containing both the mother's kidney tumors. Genomic DNA was extracted from blood leukocytes according to standard methods. Germline genomic DNA was subjected to PCR-based Sanger sequencing for the genes VHL, RET, SDHB, SDHC, and SDHD as previously performed (Neumann et al. 2002, Schiavi et al. 2005).

Corresponding normal and tumor tissues from the proband's and mother's CBTs and both kidney blocks from the mother were dissected using laser capture microdissection so that somatic DNA from the tumor and the germline DNA from the corresponding normal tissue could be isolated. Somatic loss-ofheterozygosity ( $\mathrm{LOH}) /$ allelic imbalance (AI) analyses were performed for the $S D H C$ locus and the $V H L$ locus on paired normal tumor DNA samples. LOH/AI analysis was performed using eight polymorphic 
Table 1 Loss-of-heterozygosity ( $\mathrm{LOH}$ ) findings at the SDHC locus in the carotid body tumors of the son and the mother and in the renal cell carcinomas of the mother

\begin{tabular}{|c|c|c|c|c|}
\hline \multirow[b]{2}{*}{ Marker } & \multicolumn{2}{|c|}{ Carotid body tumor } & \multicolumn{2}{|c|}{$\begin{array}{c}\text { Renal cell } \\
\text { carcinoma } \\
\text { (patient 2) }\end{array}$} \\
\hline & $\begin{array}{c}\text { Patient } 1 \\
\text { (son) }\end{array}$ & $\begin{array}{l}\text { Patient } 2 \\
\text { (mother) }\end{array}$ & ccRCC & pRCC \\
\hline D1S2707 & $x$ & $\checkmark$ & $\checkmark$ & $x$ \\
\hline D1S2771 & $x$ & $\checkmark$ & $\checkmark$ & $\checkmark$ \\
\hline D1S484 & $\checkmark$ & $\checkmark$ & $\checkmark$ & $\checkmark$ \\
\hline SDHC-CA-2 & - & $\checkmark$ & $x$ & $x$ \\
\hline SDHC-CA-3 & $\checkmark$ & $x$ & $\checkmark$ & $\checkmark$ \\
\hline SDHC-TETRA & $\checkmark$ & $\checkmark$ & $\checkmark$ & $\checkmark$ \\
\hline D1S2675 & $\times$ & $x$ & - & - \\
\hline D1S2844 & $\checkmark$ & $\checkmark$ & $x$ & $\checkmark$ \\
\hline D1S2851 & $x$ & - & $x$ & $x$ \\
\hline
\end{tabular}

$\checkmark$, LOH was detected at the marker; $\times$, the marker is heterozygous in the germline and somatic LOH was not detected; -, the marker is homozygous in the germline of that patient.

markers flanking the gene and one marker inside the SDHC gene (Table 1, Fig. 1A). The nine markers covered a total genetic distance of $10.25 \mathrm{Mb}$. As a negative control, seven markers flanking the $S D H B$ gene were analyzed as well. Each of the markers has been amplified in a PCR reaction using the Qiagen Multiplex PCR Kit. One of the two primers of each microsatellite marker was labeled with fluorescent dyes at its $5^{\prime}$-end. The PCR amplification was performed for 40 cycles after an initial $15 \mathrm{~min}$ denaturation at $95{ }^{\circ} \mathrm{C}$. Each cycle comprised $30 \mathrm{~s}$ at $94{ }^{\circ} \mathrm{C}, 90 \mathrm{~s}$ at an annealing temperature of $60^{\circ} \mathrm{C}$, and $60 \mathrm{~s}$ at $72{ }^{\circ} \mathrm{C}$ for extension. The reaction was terminated with a final 30 min extension period. PCR products were size separated on the MegaBACE 500 DNA Analysis System (Amersham Biosciences) and analyzed using MegaBACE Genetic Profiler v2.2 Software (Amersham Biosciences). LOH was scored as positive when the degree of reduction in allelic signal intensity was $>50 \%$ in one of the two alleles of the tumor DNA compared with the peaks from blood DNA. All PCR reactions showing $\mathrm{LOH}$ were independently repeated for confirmation.

For $V H L, \mathrm{LOH}$ analyses were performed using seven markers, all flanking the gene, two telomeric (D3S3691 and D3S1597) and five centromeric (D3SVHL3, D3S1337, D3SVHL7, D3SVHL8, and D3S3611; Table 2). All these markers together cover $1.66 \mathrm{Mb}$ of DNA (Fig. 1B).

In addition to LOH/AI analysis, we analyzed the tumor-derived DNA from the two paragangliomas and the two kidney carcinomas for potential somatic mutations in all exons of the $S D H C$ gene and the clear cell carcinoma for $V H L$ mutations.

\section{Results}

\section{Screening for renal neoplasias in SDHC mutation-positive registrants}

Of the 35 total registrants with germline SDHC mutations, all were strictly recommended to undergo

A

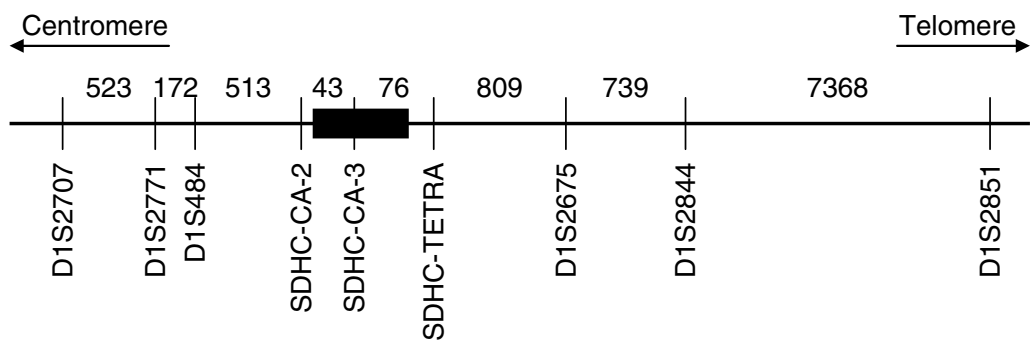

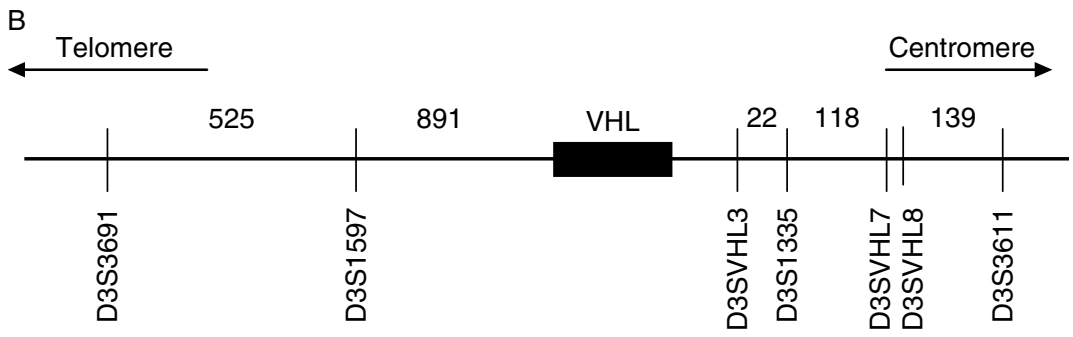

Figure 1 Physical maps and markers of the regions of the genes $S D H C$ and $V H L$. (A) Physical map of polymorphic markers within and flanking the $S D H C$ gene. Approximate distances between markers are shown in kilobases. (B) Physical map polymorphic markers of the VHL gene. Approximate distances between them are shown in kilobases. 
Table 2 Loss-of-heterozygosity ( $\mathrm{LOH}$ ) findings at the von Hippel-Lindau disease (VHL) locus in the renal cell carcinomas of the mother VHL

\begin{tabular}{lcc}
\hline & \multicolumn{2}{c}{ Renal cell carcinoma (patient 2) } \\
\cline { 2 - 3 } Marker & ccRCC & pRCC \\
\hline D3S3691 & $\checkmark$ & $\checkmark$ \\
D3S1597 & $\checkmark$ & $\checkmark$ \\
D3SVHL3 & $\checkmark$ & $\checkmark$ \\
D3S1335 & $\times$ & $\checkmark$ \\
D3SVHL7 & $\times$ & $\checkmark$ \\
d3SVHL8 & - & - \\
D3S3611 & $\checkmark$ & $\checkmark$ \\
\hline
\end{tabular}

$\checkmark$, $\mathrm{LOH}$ was detected at the marker; $\times$, the marker is heterozygous in the germline and somatic $\mathrm{LOH}$ was not detected; -, the marker is homozygous in the germline of that patient.

clinical screening by MRI of the thorax and abdomen. Ten of the 35 patients followed these recommendations, and one of the ten was found to have renal tumors. The latter was the registered mother of an index case, who was a 46-year-old male operated at age 40 for a right CBT. Postoperatively, the index case was screened for an underlying mutation, in the setting of genetic counseling; a germline c.3G $>$ A (p.M1I) mutation of $S D H C$ was found. Subsequently, he underwent clinical screening for other paraganglial system tumors, but MRI of the thorax, abdomen, and pelvis did not show abnormalities. Like the proband, the SDHC p.M1I mutation-positive mother was operated on for a CBT at age 42. At age 68 , a $6 \mathrm{~cm}$ (diameter) right renal mass was detected by MRI (Fig. 2A and B) and removed by nephrectomy. Histopathology revealed a Fuhrman grade 2 clear cell carcinoma (Fig. 2C), stage pT1b, RN0, M0. At age 69, a $2 \mathrm{~cm}$ left renal mass was detected by MRI (Fig. 3A and B) and removed by partial nephrectomy. Histopathology revealed a Fuhrman grade 2, type 1 pRCC (Fig. 3C), stage pT1a, RN0, M0.

\section{Germline mutation analysis of other RCC-related predisposition genes}

In addition to $S D H C$, germline genomic DNA of the index case's mother was subjected to PCR-based Sanger sequencing for the genes $V H L, S D H B, S D H C$, $S D H D$, and MET. No other gene, except for $S D H C$, was found to be mutated in the germline.

(a)

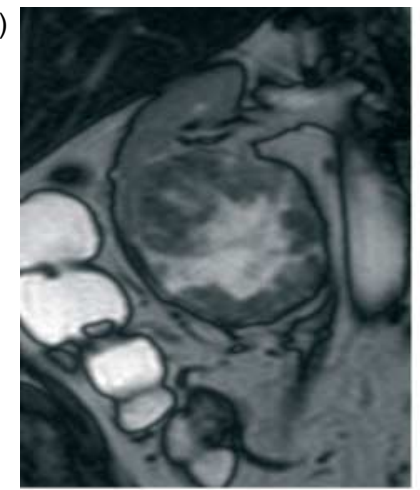

(b)

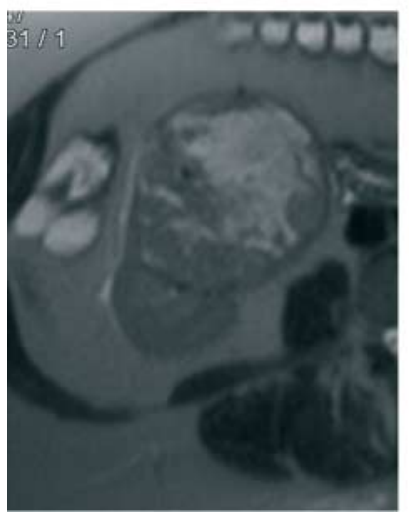

(c)

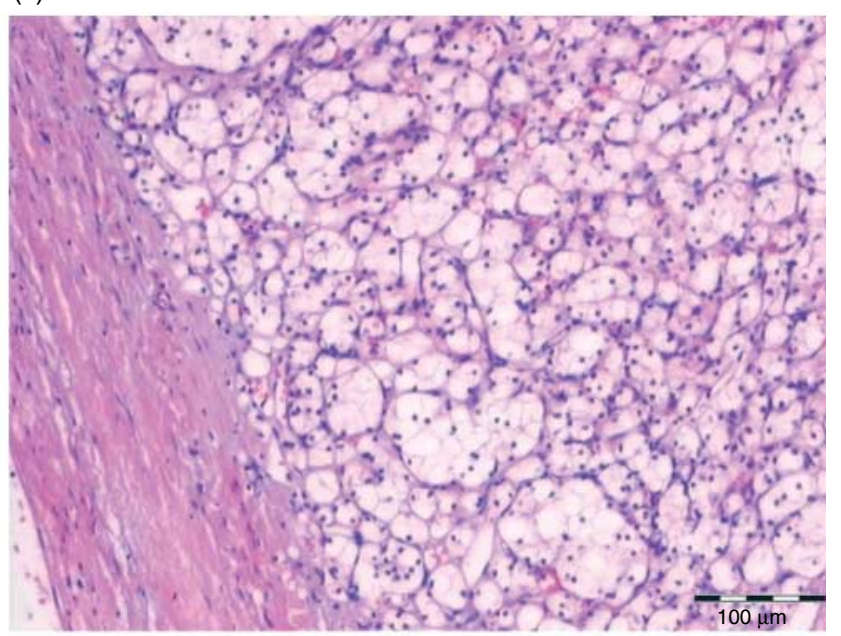

Figure 2 Clear cell carcinoma of the right kidney from the proband's mother aged 68 years. (A) Frontal view from MRI. (B) Transverse view from MRI. (C) Histology of the right kidney tumor showing clear cell carcinoma. 
(a)

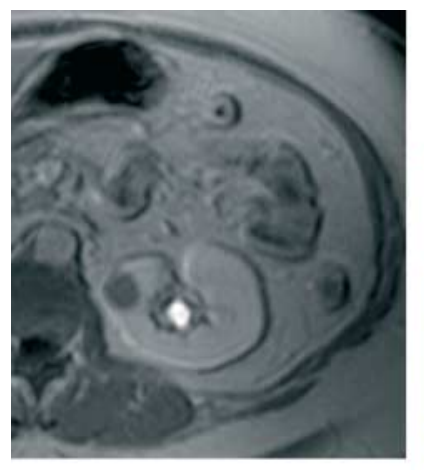

(b)

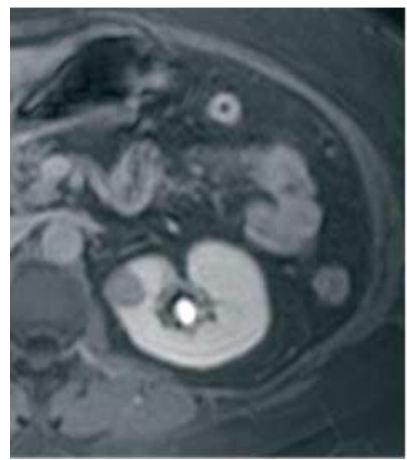

(c)

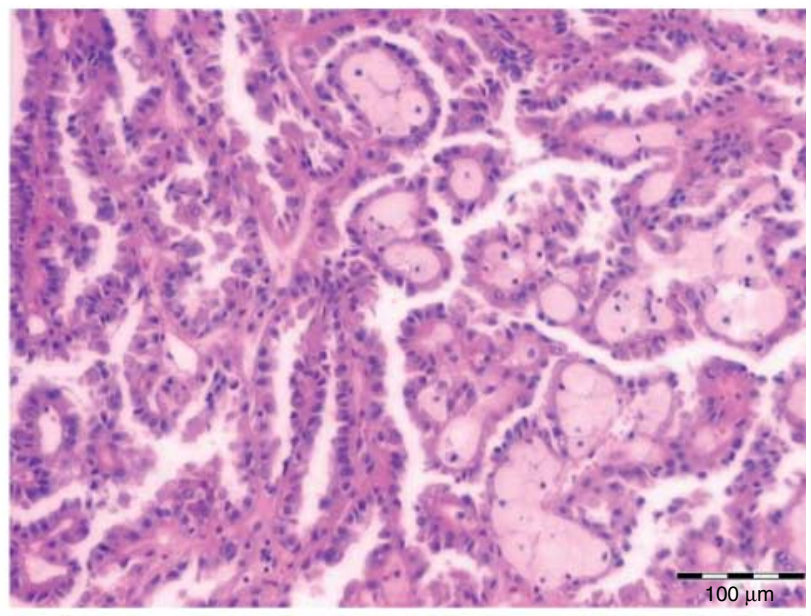

Figure 3 Papillary renal carcinoma of the left kidney from the proband's mother aged 69 years. (A) Axial T1-weighted MR image shows a hypointense $2.2 \times 1.8 \mathrm{~cm}$ mass in the anterior upper pole of the left kidney. (B) Axial contrast-enhanced MR image shows only slight homogeneous enhancement. (C) Histology of the left kidney tumor showing papillary renal cell carcinoma.

\section{LOH/Al analysis}

\section{Carotid body tumors}

The analysis of the nine $S D H C$-defining polymorphic markers revealed $\mathrm{LOH}$ of centromeric and telomeric markers of the $S D H C$ gene in the paragangliomas from the proband and his mother (Fig. 1A). In addition, the proband's CBT showed clear $\mathrm{LOH}$ in the marker within the SDHC gene (SDHC-CA-3; Supplementary Figure 1, see section on supplementary data given at the end of this article). In the CBT of the proband's mother, $\mathrm{LOH}$ was demonstrated in all centromeric markers and in two of three informative telomeric markers. Of note, the intragenic marker SDHC-CA-3 (within intron 4), which underwent $\mathrm{LOH}$ in the son's tumor, retained heterozygosity in the mother's tumor (Supplementary Figure $2 \mathrm{~A}$, see section on supplementary data given at the end of this article). It should be noted that SDHCCA-2 is only $3 \mathrm{~kb}$ upstream of exon 1 and SDHCTETRA is only $68 \mathrm{~kb}$ downstream of exon 6 and both underwent LOH in the mother's CBT (Fig. 1A).

\section{Kidney tumors}

We analyzed both renal carcinomas from the proband's mother, who had a clear cell cancer, followed by a type I papillary carcinoma of the contralateral kidney a year later. Because of the known role of $V H L$ and the suspected role of $S D H C$ in renal carcinomas, we performed $\mathrm{LOH}$ analysis of markers within and flanking both $S D H C$ and $V H L$ (Fig. 1), and we also inspected the sequencing chromatogram using tumor DNA as template (Fig. 4). In addition, the pRCC was shown to have somatic LOH of SDHC minimally ranging from D1S2771 to D1S2844, a distance of $9.7 \mathrm{Mb}$. The ccRCC showed $\mathrm{LOH}$ of all three informative SDHC centromeric markers (D1S2707, D1S2771, and D1S484), the intragenic marker (SDHCCA-3; Supplementary Figure 2B and C, see section on supplementary data given at the end of this article), and one telomeric marker (SDHC-TETRA). LOH of the VHL gene, spanning D3S3691 to D3S3611 (and potentially distally), was evident in the pRCC (Table 2). For the clear cell renal carcinoma, LOH was found in two telomeric markers (D3S3691 and D3S1597) and in two centromeric markers (D3SVHL3 and D3S3611). As a negative control, we showed that the seven markers defining $S D H B$ retained heterozygosity in both renal tumors.

Immunochemistry for $S D H B$ has been performed for both kidney carcinomas and for the paragangliomas of the mother and the son. The paragangliomas of the son and the mother showed negative $S D H B$ 


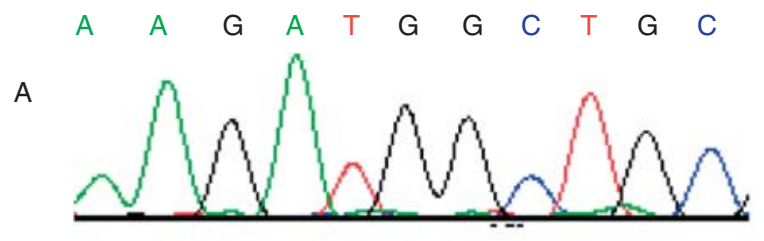

B

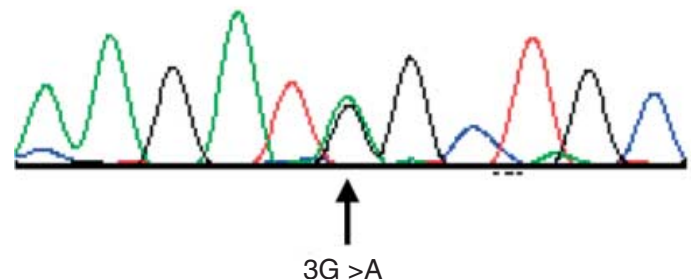

C

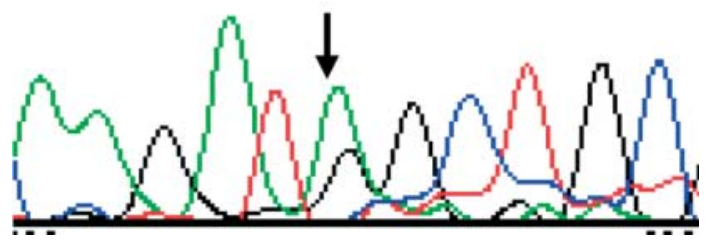

Figure 4 Sequencing chromatograms of the region defined by the $S D H C$ germline mutation M1I using germline and somatic tumor templates. (A) DNA sequence chromatogram of wild-type (WT) SDHC. (B) DNA sequence chromatogram of the patient's germline DNA showing the germline mutation (indicated by an arrow). (C) Sequencing of tumor-derived DNA in the area of the germline mutation.

immunostaining as expected. $S D H B$ immunostaining was negative for the ccRCC as expected but clearly positive in the pRCC, which is so far unexplained. The normal tissue components in the slides of the kidney tumors were positive as expected.

\section{Discussion}

RCC is a relatively uncommon disease, but it is the most common type of kidney neoplasia in adults and, recently, has served as a paradigmatic cancer for molecular targeted therapies. Paradoxically, however, the pathogenesis and etiology of RCC are at best partially understood. Major gains of knowledge regarding etiology and pathogenesis have come from hereditary RCC predisposition syndromes, chief of which is VHL disease caused by germline mutations of the VHL gene (Latif et al. 1993, Zbar et al. 1996, Neumann \& Zbar 1997, Neumann et al. 1998, Delahunt \& Eble 2004, Grignon et al. 2004, Maher et al. 2011). Remarkably, germline mutations of $S D H B$ have been found in patients with ccRCC and RCC with a distinct solid histology (Vanharanta et al. 2004, Ricketts et al. 2008, Gill et al. 2011a,b). Germline mutations of $M E T$ or $F H$ have been reported in patients with pRCC, the former type 1 and the latter type 2
(Schmidt et al. 2001, Tomlinson et al. 2002). In the setting of Cowden and Cowden-like syndromes, germline $S D H B / S D H D$ mutations/variants were found to associate with higher prevalence of breast, thyroid, and renal cell cancers (Ni et al. 2008, 2012). Similarly, germline epimutation of $K L L N$, which shares a bidirectional promoter with PTEN, was associated with Cowden and Cowden-like syndrome and confers a higher risk of breast and renal carcinomas (Bennett et al. 2010). Subsequently, germline KLLN epimutation was shown to be associated with a subset of apparently sporadic ccRCC, with increased somatic KLLN methylation noted in the matched ccRCC tumors (Bennett et al. 2011). Somatic LOH has been identified in the VHL gene in VHL-associated ccRCC and somatic LOH of the $S D H B$ gene in ccRCC from patients with germline SDHB mutations (Vanharanta et al. 2004, Ricketts et al. 2008). Somatic mutations with biallelic inactivation of the VHL gene in ccRCC has been shown by Foster et al. (1994) and Shuin et al. (1994) and somatic gain-of-function mutations of the MET gene in pRCC has also been reported (Schmidt et al. 1997). Thus, we believe that uncovering the molecular pathogenesis of RCC associated with heritable disease will lend useful clues to RCC pathogenesis in general.

In this study, we systematically interrogated our population-based registry for $S D H C$ mutation-positive participants who also had RCC. Of those who took up our surveillance recommendations, one registrant $(10 \%)$ was found to have metachronous bilateral RCC of clear cell and papillary histologies. Bilateral involvement is a clinical red flag suggesting heritable disease. However, because the RCCs occurred at an age that is no different from the general population, we proceeded to show that biallelic inactivation by somatic deletion of the remaining wild-type allele occurred in both the RCCs. In contrast, SDHB LOH was absent in both RCC tumors. Neither somatic intragenic mutations of $S D H C$ or $V H L$ were found. Only somatic LOH of the VHL locus was found in the pRCC but surprisingly not present in the ccRCC.

Neither the mother's right kidney ccRCC nor the left-sided type 1 pRCC showed the morphology described for germline $S D H B$ mutation-associated renal carcinomas described by Gill et al. $(2011 a, b)$. The $S D H B$-related renal tumors showed formation into solid nests or in tubules with cuboidal cells, eosinophilic cytoplasm, cytoplasmic inclusions, and indistinct borders, all of which did not appear to be present in these $S D H C$-related kidney cancers.

Because germline $S D H C$ mutations are relatively uncommon in our population-based registry compared 
with $S D H B$ and $S D H D$ mutation-positive participants, it is unclear whether further RCC will develop in the registrants with longer follow-up. For example, it was believed that carriers of mutations of the $S D H C$ gene have an exclusive risk for head and neck paragangliomas but also subsequently shown to be at a risk for adrenal pheochromocytoma (Schiavi et al. 2005). Therefore, the number of patients who have been subjected to a complete clinical screening of the paraganglial system including MRI of the abdomen is limited. In fact, only ten out of 35 identified SDHC mutation carriers in the European-American Pheochromocytoma and Paraganglioma Registry had thus radiological imaging of the kidneys.

In summary, we have found, despite small sample sizes in our population-based registry, that $10 \%$ of individuals with $S D H C$ gene mutation develop RCC, at least of clear cell and papillary histology, both of which show second allele somatic inactivation by deletion. If this observation can be replicated in other studies, they suggest that RCC may be a new component of $S D H C$ related PGL. Further, our hypothesis-generating observation suggest that biallelic inactivation of the $S D H C$ gene could be a new molecular pathway for the pathogenesis of RCC and this should be explored in both heritable and sporadic settings.

\section{Supplementary data}

This is linked to the online version of the paper at http://dx. doi.org/10.1530/ERC-11-0324.

\section{Declaration of interest}

The authors declare that there is no conflict of interest that could be perceived as prejudicing the impartiality of the research reported.

\section{Funding}

H P H Neumann is supported by a grant from the German Research Foundation (Deutsche Forschungsgemeinschaft Ne 571/4-6). C Eng is the J Sondra and Stephen R Hardis Chair of Cancer Genomic Medicine at the Cleveland Clinic, and is an ACS Clinical Research Professor, generously funded in part by the F M Kirby Foundation, and the Arthur Blank Foundation, Atlanta, GA, USA.

\section{References}

Bennett KL, Mester J \& Eng C 2010 Germline epigenetic regulation of KILLIN in Cowden and Cowden-like syndrome. Journal of the American Medical Association 304 2724-2731. (doi:10.1001/jama.2010.1877)
Bennett KL, Campbell R, Ganapathi S, Zhou M, Rini B, Ganapathi R, Neumann HP \& Eng C 2011 Germline and somatic DNA methylation and epigenetic regulation of KILLIN in renal cell carcinoma. Genes, Chromosomes \& Cancer 50 654-661. (doi:10.1002/gcc.20887)

Cohen HT \& McGovern FJ 2005 Renal-cell carcinoma. New England Journal of Medicine 353 2477-2490. (doi:10.1056/NEJMra043172)

Delahunt B \& Eble JN 2004 Papillary renal cell carcinoma. In Pathology and genetics of tumours of the urinary system and male genital organs. World Health Organization Classification of Tumours, pp 27-29. Eds JN Eble, G Sauter, JI Epstein \& IA Sesterhenn. Lyon, France: IARC Press.

Foster K, Prowse A, van den Berg A, Fleming S, Hulsbeek MM, Crossey PA, Richards FM, Cairns P, Affara NA, FergusonSmith MA et al. 1994 Somatic mutations of the von Hippel-Lindau disease tumour suppressor gene in nonfamilial clear cell renal carcinoma. Human Molecular Genetics 3 2169-2173. (doi:10.1093/hmg/3.12.2169)

Gill AJ, Pachter NS, Chou A, Young B, Clarkson A, Tucker KM, Winship IM, Earls P, Benn DE, Robinson BG et al. 2011a Renal tumors associated with germline SDHB mutation show distinctive morphology. American Journal of Surgical Pathology 35 1578-1585. (doi:10.1097/PAS.0b013e318227e7f4)

Gill AJ, Pachter NS, Clarkson A, Tucker KM, Winship IM, Benn DE, Robinson BG \& Clifton-Bligh RJ $2011 b$ Renal tumors and hereditary pheochromocytomaparaganglioma syndrome type 4. New England Journal of Medicine 364 885-886. (doi:10.1056/NEJMc1012357)

Grignon DJ, Eble JN, Bonsib SM \& Moch H 2004 Clear cell renal cell carcinoma. In Pathology and genetics of tumours of the urinary system and male genital organs. World Health Organization Classification of Tumours, pp 27-29. Eds JN Eble, G Sauter, JI Epstein \& IA Sesterhenn. Lyon, France: IARC Press.

Khoo SK, Giraud S, Kahnoski K, Chen J, Motorna O, Nickolov R, Binet O, Lambert D, Friedel J, Levy R et al. 2002 Clinical and genetic studies of Birt-Hogg-Dube syndrome. Journal of Medical Genetics 39 906-912. (doi:10.1136/jmg.39.12.906)

Latif F, Tory K, Gnarra J, Yao M, Duh FM, Orcutt ML, Stackhouse T, Kuzmin I, Modi W, Geil L et al. 1993 Identification of the von Hippel-Lindau disease tumor suppressor gene. Science 260 1317-1320. (doi:10.1126/science.8493574)

Lonser RR, Glenn GM, Walther M, Chew EY, Libutti SK, Linehan WM \& Oldfield EH 2003 von Hippel-Lindau disease. Lancet 361 2059-2067. (doi:10.1016/S01406736(03)13643-4)

Maher ER, Neumann HP \& Richard S 2011 von HippelLindau disease: a clinical and scientific review. European Journal of Human Genetics 19 617-623. (doi:10.1038/ejhg.2010.175)

Neumann HP \& Zbar B 1997 Renal cysts, renal cancer and von Hippel-Lindau disease. Kidney International 51 16-26. (doi:10.1038/ki.1997.3) 
Neumann HP, Bender BU, Berger DP, Laubenberger J, Schultze-Seemann W, Wetterauer U, Ferstl FJ, Herbst EW, Schwarzkopf G, Hes FJ et al. 1998 Prevalence, morphology and biology of renal cell carcinoma in von Hippel-Lindau disease compared to sporadic renal cell carcinoma. Journal of Urology 160 1248-1254. (doi:10.1016/S0022-5347(01)62509-6)

Neumann HP, Bausch B, McWhinney SR, Bender BU, Gimm O, Franke G, Schipper J, Klisch J, Altehoefer C, Zerres K et al. 2002 Germ-line mutations in nonsyndromic pheochromocytoma. New England Journal of Medicine 346 1459-1466. (doi:10.1056/NEJMoa020152)

Neumann HP, Pawlu C, Peczkowska M, Bausch B, McWhinney SR, Muresan M, Buchta M, Franke G, Klisch J, Bley TA et al. 2004 Distinct clinical features of paraganglioma syndromes associated with SDHB and SDHD gene mutations. Journal of the American Medical Association 292 943-951. (doi:10.1001/jama. 292.8.943)

Ni Y, Zbuk KM, Sadler T, Patocs A, Lobo G, Edelman E, Platzer P, Orloff MS, Waite KA \& Eng C 2008 Germline mutations and variants in the succinate dehydrogenase genes in Cowden and Cowden-like syndromes. American Journal of Human Genetics 83 261-268. (doi:10.1016/j. ajhg.2008.07.011)

Ni Y, He X, Chen J, Moline J, Mester J, Orloff MS, Ringel MD \& Eng C 2012 Germline SDHx variants modify breast and thyroid cancer risks in Cowden and Cowden-like syndrome via FAD/NAD-dependant destabilization of p53. Human Molecular Genetics 21 300-310. (doi:10.1093/hmg/ddr459)

Pavlovich CP \& Schmidt LS 2004 Searching for the hereditary causes of renal-cell carcinoma. Nature Reviews. Cancer 4 381-393. (doi:10.1038/nrc1364)

Peczkowska M, Cascon A, Prejbisz A, Kubaszek A, Cwikla BJ, Furmanek M, Erlic Z, Eng C, Januszewicz A \& Neumann HP 2008 Extra-adrenal and adrenal pheochromocytomas associated with a germline SDHC mutation. Nature Clinical Practice. Endocrinology \& Metabolism 4 111-115. (doi:10.1038/ncpendmet0726)

Ricketts C, Woodward ER, Killick P, Morris MR, Astuti D, Latif F \& Maher ER 2008 Germline SDHB mutations and familial renal cell carcinoma. Journal of the National Cancer Institute 100 1260-1262. (doi:10.1093/jnci/ djn254)

Schiavi F, Boedeker CC, Bausch B, Peczkowska M, Gomez CF, Strassburg T, Pawlu C, Buchta M, Salzmann M, Hoffmann MM et al. 2005 Predictors and prevalence of paraganglioma syndrome associated with mutations of the SDHC gene. Journal of the American Medical Association 294 2057-2063. (doi:10.1001/jama. 294.16.2057)
Schmidt L, Duh FM, Chen F, Kishida T, Glenn G, Choyke P, Scherer SW, Zhuang Z, Lubensky I, Dean M et al. 1997 Germline and somatic mutations in the tyrosine kinase domain of the MET proto-oncogene in papillary renal carcinomas. Nature Genetics 16 68-73. (doi:10.1038/ng0597-68)

Schmidt LS, Warren MB, Nickerson ML, Weirich G, Matrosova V, Toro JR, Turner ML, Duray P, Merino M, Hewitt S et al. 2001 Birt-Hogg-Dube syndrome, a genodermatosis associated with spontaneous pneumothorax and kidney neoplasia, maps to chromosome 17p11.2. American Journal of Human Genetics 69 876-882. (doi:10.1086/323744)

Schmidt LS, Nickerson ML, Angeloni D, Glenn GM, Walther MM, Albert PS, Warren MB, Choyke PL, Torres-Cabala CA, Merino MJ et al. 2004 Early onset hereditary papillary renal carcinoma: germline missense mutations in the tyrosine kinase domain of the met protooncogene. Journal of Urology 172 1256-1261. (doi:10. 1097/01.ju.0000139583.63354.e0)

Shuin T, Kondo K, Torigoe S, Kishida T, Kubota Y, Hosaka M, Nagashima Y, Kitamura H, Latif F, Zbar B et al. 1994 Frequent somatic mutations and loss of heterozygosity of the von Hippel-Lindau tumor suppressor gene in primary human renal cell carcinomas. Cancer Research 54 2852-2855.

Tomlinson IP, Alam NA, Rowan AJ, Barclay E, Jaeger EE, Kelsell D, Leigh I, Gorman P, Lamlum H, Rahman S et al. 2002 Germline mutations in FH predispose to dominantly inherited uterine fibroids, skin leiomyomata and papillary renal cell cancer. Nature Genetics 30 406-410. (doi:10. 1038/ng849)

Vanharanta S, Buchta M, McWhinney SR, Virta SK, Peczkowska M, Morrison CD, Lehtonen R,

Januszewicz A, Jarvinen H, Juhola M et al. 2004 Early-onset renal cell carcinoma as a novel extraparaganglial component of SDHB-associated heritable paraganglioma. American Journal of Human Genetics 74 153-159. (doi:10.1086/381054)

Zbar B, Kishida T, Chen F, Schmidt L, Maher ER, Richards FM, Crossey PA, Webster AR, Affara NA, Ferguson-Smith MA et al. 1996 Germline mutations in the von Hippel-Lindau disease (VHL) gene in families from North America, Europe, and Japan. Human Mutation 8 348-357. (doi:10.1002/(SICI)10981004(1996)8:4<348::AID-HUMU8> 3.0.CO;2-3)

Received in final form 7 February 2012 Accepted 14 February 2012 Made available online as an Accepted Preprint 20 February 2012 